Hernández Robles, Edgar Carlos.

Profesor, Universidad Nacional Autónoma de México, Facultad de Artes y Diseño.

\title{
Cargo Culte: La estética del Culto de cargo \\ en el contexto urbano posindustrial de la Ciudad de México.
}

\section{Cargo Culte: The aesthetics of Cargo Cults in the post-industrial urban context of Mexico City.}

TIPO DE TRABAJO:

Comunicación.

PALABRAS CLAVE:

Dibujo, dispositivo, decolonial, bricoleur, cargo cult.

KEY WORDS:

Drawing, dispositif, decolonial, bricoleur, cargo cult.

RESUMEN.

La Ciudad de México ha visto en los últimos veinte años diversas formas de habitar sus espacios públicos, convertidos también en espacios de conflicto por las condiciones geo-políticas imperantes, estos no-sitios han sido poblados por manifestaciones estéticas, todas coincidentes en una gramática visual de la apropiación, el emplazamiento y la acumulación de objetos en desuso, chatarra y demás excedentes de un sistema económico alguna vez promesa de modernidad que nunca llegó. Este proyecto construyó un puente entre estas manifestaciones estéticas urbanas con el fenómeno aparecido durante la Segunda Guerra Mundial en las islas de Oceanía Remota: los cargo cults, mito que incubó los movimientos de independencia en este archipiélago. La investigación abordó éste puente desde el dibujo en la noción de dispositivo: entidad transversal, heurística y autónoma que a partir de una estrategia situacionista generó una taxonomía conformada por 22 láminas de medio tono a la usanza de la ilustración científica, la cual recopiló diversos ensamblajes en la ciudad utilizando la deriva como trabajo de campo teniendo en común una específica carga simbólica emancipatoria y todos ellos siendo construidos por bricoleurs: creadores anónimos-colectivos. Esta tesis contribuye al estudio del dibujo como un dispositivo, que opera como palanca para articular ideas, aprehender el mundo y colaborar en nuevos saberes universales, decoloniales y emancipatorios como posibilidades de afirmación colectiva. 


\section{ABSTRACT.}

Over the last 20 years Mexico City has witnessed a remarkable take over of the public space, becoming the ideal venue for the sprout of very unique aesthetic manifestations, which reflect the specific geopolitical conditions the metropolis has experienced throughout these years.

Urban non-sites have become home to a diverse set of anonymous assemblages created by bricoleurs -anonymous, collective authors - with discarded objects, junk and other surplus of an economic system once the promise of a modernity which never came, each and every one of them featuring a visual grammar that consists of appropriation, site-specific relevance and accumulation.

This project builds a bridge between these assemblages and cargo cults, a phenomenon appeared during World War II in New Guinea: a native myth which eventually triggered the independence movements in the Islands.

Using the Situationist strategy of derive to approach these street assemblages as material expressions with an aesthetic and symbolical cargo, and drawing as a dispositif -intended as a transversal, autonomous and heuristic entity-, the urban field-work generated a taxonomy of twenty-two halftone plates in the style of scientific illustration.

This thesis contributes to the field of study of drawing as a dispositif, which operates as a lever to articulate ideas, to help grasp the world and collaborate in the development of universal, decolonial and emancipating knowledge as a means to collective identity affirmation. 